\title{
Business Innovation and Service Innovation: Perspective on Product Design Engineering in Term of User Experience (UX)
}

\section{Khristian Edi Nugroho Soebandrija}

Industrial Engineering Department, Faculty of Engineering, Program of Doctor of Research in Management (DRM). Bina Nusantara University, JI. K H. Syahdan No. 9, Kemanggisan - Palmerah, Jakarta, Indonesia 11480

\section{Abstract}

Business innovation is one of the factors driving a company for providing values for stakeholders toward sustainable competitive advantages. The mentioned values vis-àvis not merely internal stakeholders, but also external stakeholders. Subsequently, this paper elaborates grand theory within stakeholders theory. The mentioned sustainable competitive advantages are achieved through the disruptive innovation that revamps the constellation of sustainable competitive advantages. The disruptive innovation is

Corresponding Author: Khristian Edi Nugroho Soebandrija Knugroho@binus.edu Khristian.DRM@gmail.com

Received: 16 February 2020 Accepted: 5 March 2020

Published: 10 March 2020

Publishing services provided by Knowledge $\mathrm{E}$

\section{(c) Khristian Edi Nugroho}

Soebandrija. This article is distributed under the terms of the Creative Commons

Attribution License, which permits unrestricted use and redistribution provided that the original author and source are credited.

Selection and Peer-review unde the responsibility of the ICLBI (2018) Conference Committee.

\section{G OPEN ACCESS} implemented and intertwined through industry 4.0 that covers trilogy of physical, digital, and biology. Subsequently, the mentioned implementation is geared toward benefits of Making Indonesia 4.0 through Indonesia local wisdom and setting. Precisely, it further elaborates the Product Design Engineering (PDE). This PDE discipline incorporates the concept of its evolutionary theories from cognitive psychology; human factors in product design; kansei engineering; emotional design; affective engineering; and user experience design

Keywords: Affective engineering; cognitive psychology; disruptive innovation; kansel engineering; user empathy

\section{Introduction}

This paper provides grand theory on service innovation. This grand theory was originally initially by Schumpeter through his innovation theory [1,2]. This service innovation theory is intertwined with the theory of capability-rigidity paradox theory $[3,4]$. In this paper, business innovation constitutes a trigger point for service innovation in order to create product and service that relate to product design engineering [5].

In this paper, the grand theory on service innovation elaborates subsequently the perspectives of product design engineering, vis-à-vis both theoretical and empirical perspectives of business innovation, industry 4.0 and Making Indonesia 4.0. This paper elaborates the service innovation that is beneficial for managerial implementation and 
its implication in product design engineering. Precisely, product design engineering from concept of user experience, known as UX.

\section{Problem statement}

Problem statement in this paper refers to how tackle the managerial implementation of service innovation within the product design engineering perspective, from the concept of user experience, known as UX. Previously UX by perception has been associated with software development. Conversely, in Product Design Engineering (PDE) program; this perception is elaborated in innovated spectrum. The mentioned spectrum is intended to trigger leaping process for product design engineers the frontier of the new competencies far exceeding classical form-giving, in term of user experience (UX) dimensions.

\section{Research questions}

The principal research questions in this paper comprise two questions. The first question refers to the inquiry toward to what optimal level that the UX has evolved as compared to prior evolution from the arching theory of service innovation relates to other theories as stated in this paper. Subsequently, the second question refers to the inquiry toward to what extent the theoretical aspects in the first question can be implemented evolution of research domains related to the UX of Products, by balancing the industry 4.0. Precisely, this question relates to inquiry on how to harness the industry 4.0 with Making Indonesia 4.0 's local wisdom and setting.

\section{Purpose of the study}

The objective of the study is to provide frontier on the theoretical aspect of service innovation that relates to product design engineering, from concept of UX. The mentioned frontier is subsequently explored to provide empirical benefits toward the managerial implementation within product design engineering perspectives, from concept of UX.

\section{Conceptual models}

In line with Schumpeter [2]; define service innovations as technology-based inventions, driven by the emergence of new markets or new service opportunities. Meanwhile, 
research works of this theory provide a different definition of service innovations as changes in the process of producing lines, improvements in risk assessment, in marketing and in organization [6].

The Bongard-Blanchy and Bouchard indicate user UX dimensions that potentially impact how users' experience products. These dimensions are brought together from theories of cognitive science, models of human-computer interaction and findings from design research [7]. They are presented under four categories: dimensions of human perception, dimensions of products, dimensions of the context of use and the temporal dimension. In the final part, the identified dimensions are connected into a schema, illustrating their interplay and therefore the journey of UX between a user and a product, in a certain context over a certain time.

Figure 1, depicts several evolutions of research domains in product design engineering in term of UX of Products, as the result of scholar works by Bongard-Blanchy and Bouchard [7]. First, researchers in cognitive psychology were the scholar works that embark the human perception of objects [8]. With the creation of early years for personal computers, the domain of human-computer interaction emerged as a vehicle to augment usability of graphical interfaces [9]. Second, in the product design domain, the scholar works of human factors gained significance for the same objective: that of optimizing usability [10, 11]. Third, researchers of "Kansei Engineering" [12] in Asia were the scholar works that initiate and anticipate the emotions, sensations, and semantics conveyed by product design engineering perspectives. Fourth, in the Western world, the start of the new century saw the advent of research into "Emotional Design"; the study of the emotional value of products [13]. Fifth, furthermore researcher of "Affective Engineering" investigate the sensorial experience evoked by materials and textures [14].

Sixth, while UX is still commonly associated with the realm of human-computer interaction, other domains such as product or service design integrates the findings of these various domains under the paradigm of UX design/experience design [15].

Figure 2, illustrates and elaborates schema of the dimension of the user-product experience, as indicated by Bongard-Blanchy and Bouchard [7]. Through this literature review, they have sought to demonstrate how UX results from the interplay of a wide range of concrete (form, colour, semantic, function) and abstract (affective and sensorial quality, semantic quality, aesthetic quality) product dimensions, together with their perception by the target user, the context in which s/he encounters the product and the temporality of the experience. The mentioned Figure 2 , is further illustrated in detail in Figure 3 and Figure 4, in term of user and product, respectively. 


\section{$\begin{array}{llllll}1960 & 1970 & 1980 & 1990 & 2000 & 2010\end{array}$}

\section{Cognitive Psychology}

\section{Human Factors in Product Design}

\section{Kansei Engineering}

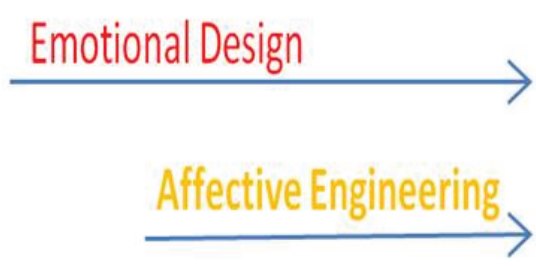

User Experience Design

Figure 1: Evolution of research domains related to the UX of products.

Subsequently, in Figure 5, Bongard-Blanchy and Bouchard indicate that nowadays product engineer has challenges to espouse a holistic view of UX vis-à-vis conceptual design and design evaluation [7]. That challenges construe, the conceptual design should always aim congruence between identified, and potentially evolving user goals and the product purpose.

\section{Conclusion}

A problem statement in this paper refers to how tackle the managerial implementation of service innovation within the product design engineering perspective, from concept of user experience, known as UX. Thus, this paper has already addressed this problem statement and interpreted it into research questions that have similarly been modeled.

The posed research questions refer to i) optimal level that the UX has evolved as compared to prior evolution from the arching theory of service innovation relates to other theories as stated in this paper; and ii) to what extent the theoretical aspects in the first question can be implemented Evolution of research domains related to the UX of products, by balancing the industry 4.0 . 


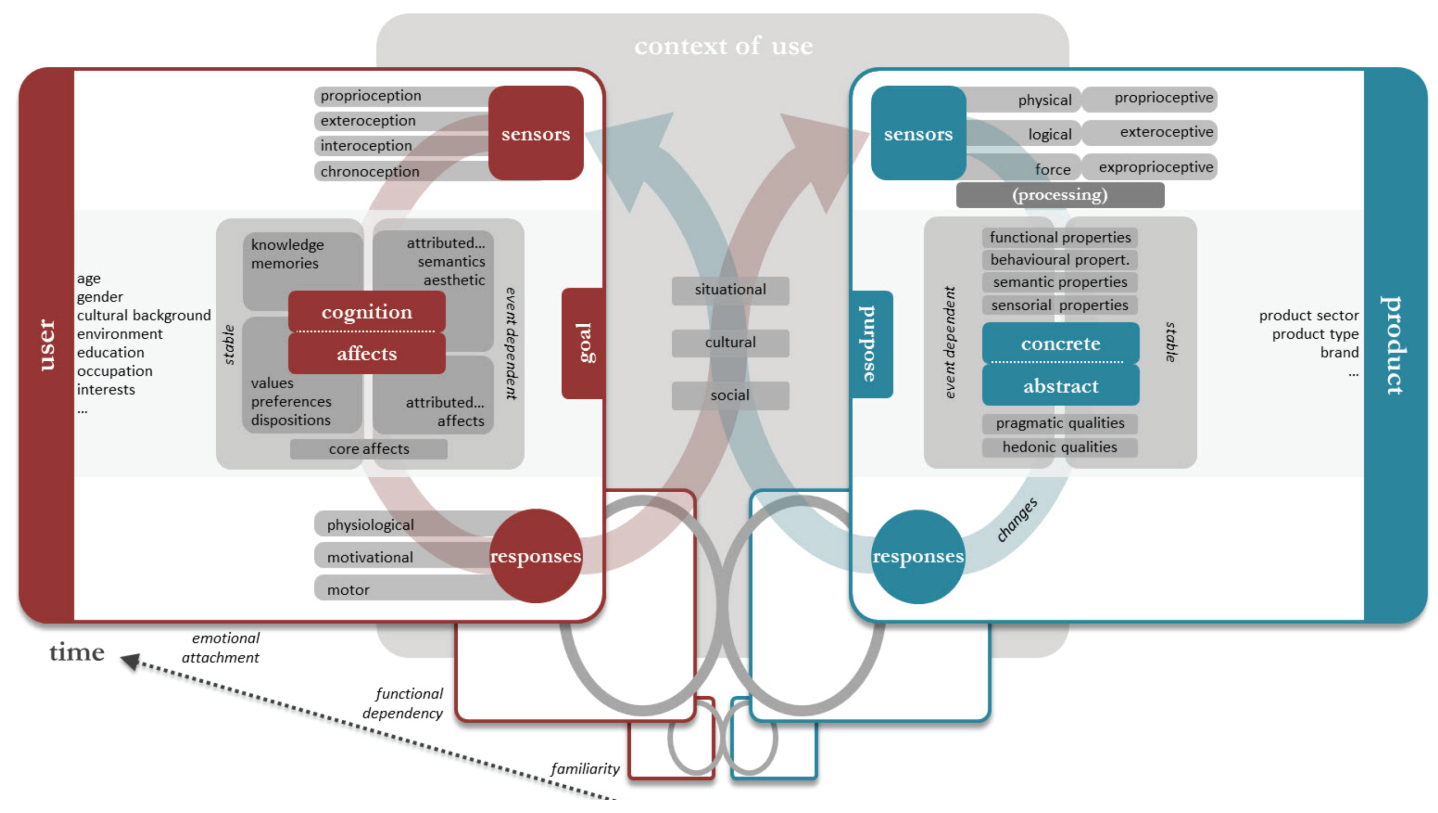

Figure 2: Schema of the dimension of the user-product experience.

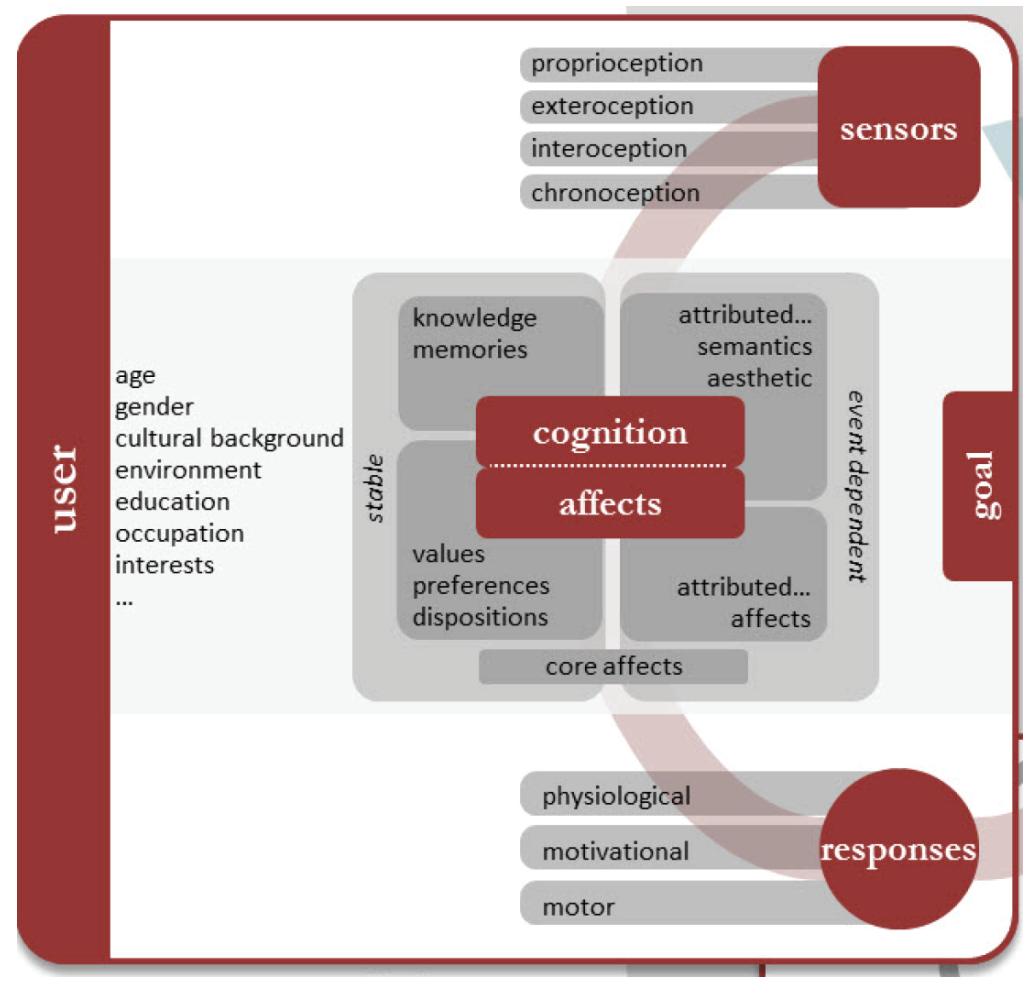

Figure 3: Schema of the dimension of the user experience.

Ultimately, the objective of the study has been achieved. Precisely, this paper has its objective to provide frontier on the theoretical aspect of service innovation that relate to product design engineering, from concept of UX. 


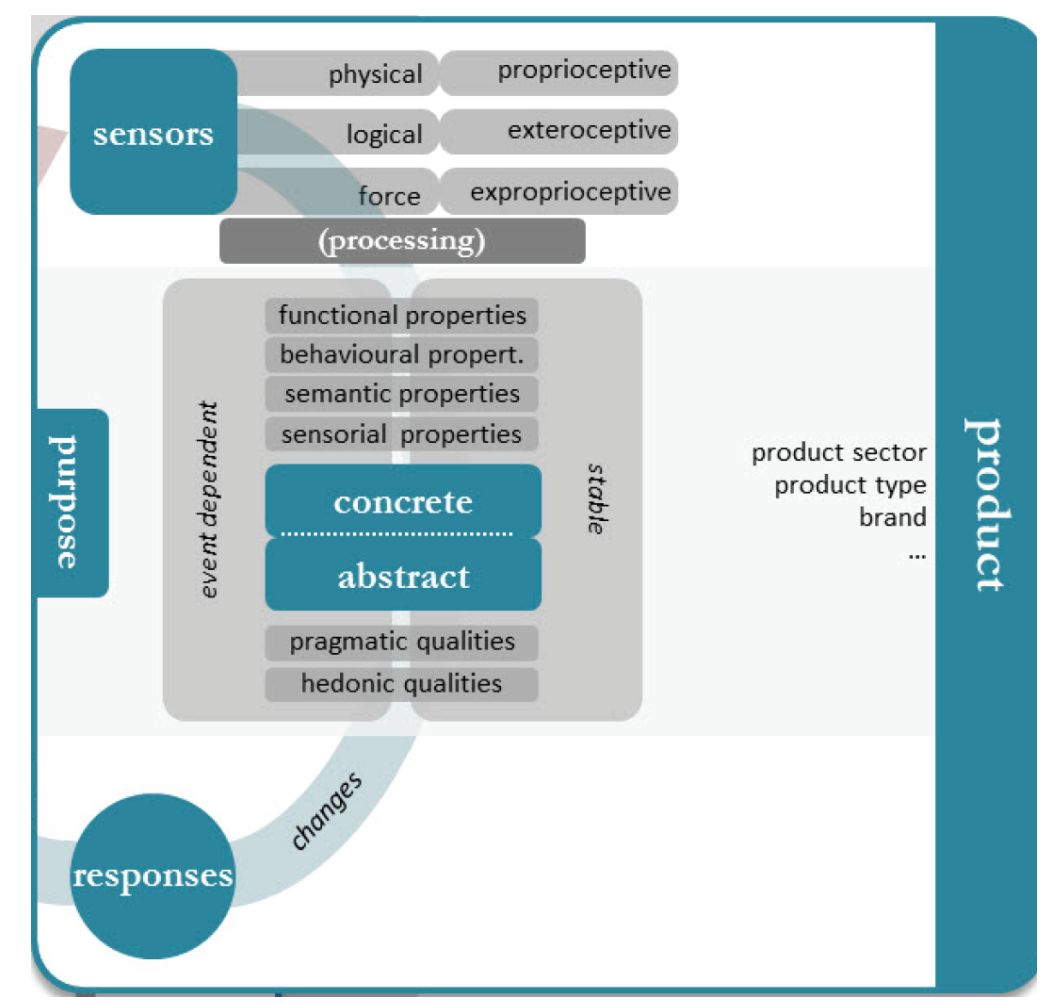

Figure 4: Schema of the dimension of the product experience.
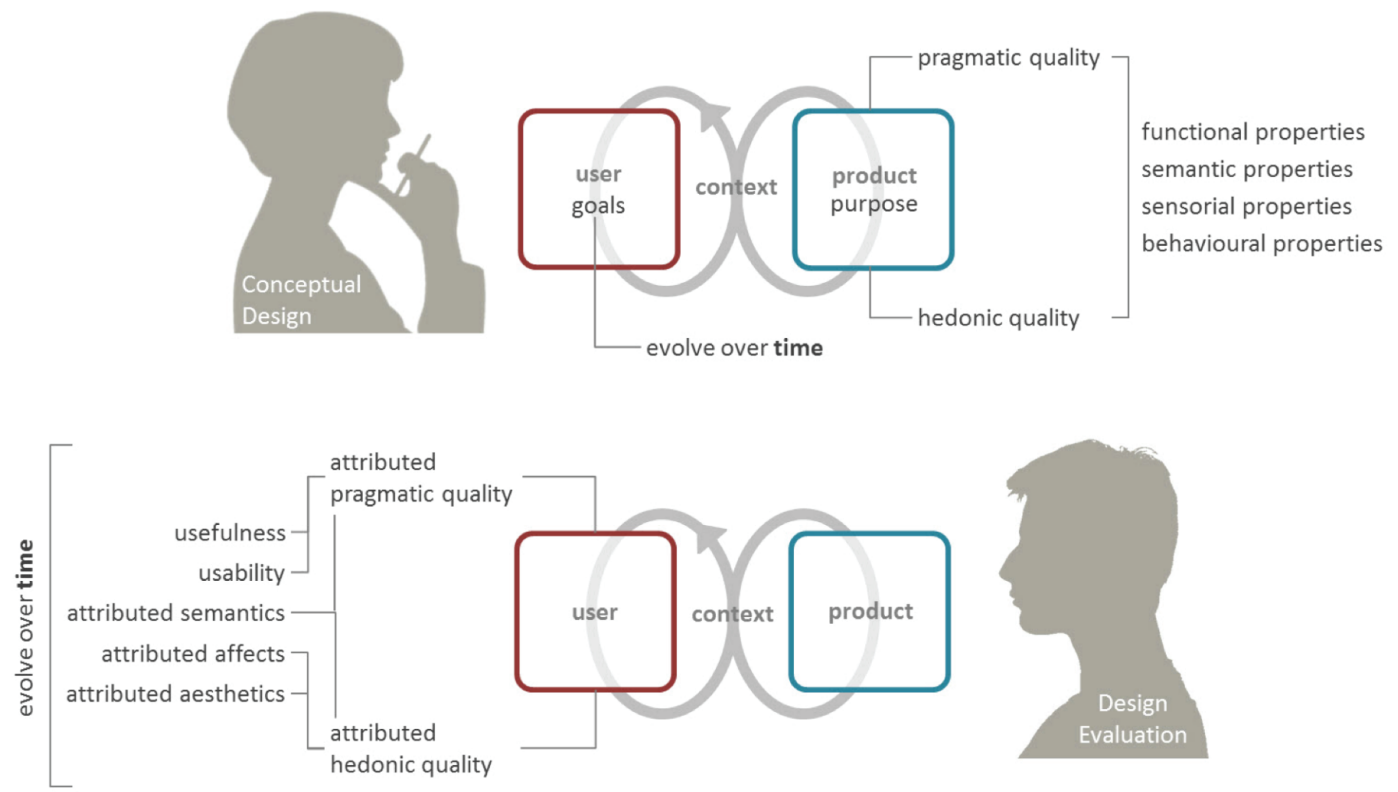

Figure 5: Dimensions of conceptual design (top) and design evaluation (bottom) when designing for UX.

The product design engineer harmonizes function, semantic, sensorial and behavioral properties vis à vis hedonic and pragmatic quality. To validate and improve the designed experience, concepts and prototypes should then be recurrently evaluated 
through user tests. These evaluations authenticate which pragmatic and hedonic qualities the user really attributes to the designed product.

As conclusion, there are beneficial aspects in term of UX dimensions. Precisely, this perspective is applicable in product design engineering perspectives. In this situation this perspective is elaborated in innovated spectrum. The mentioned spectrum is intended to spectacle product design engineers the frontier of the new competencies far beyond classical form-giving, in term of user experience (UX) dimensions.

\section{References}

[1] Rong D, Ming X, Limsupanark J. The theoretical study and empirical research process of service innovation: a literature review. International Business Research, 2015; 8(1). http://www.ccsenet.org/journal/index.php/ibr/article/view/38694

[2] Schumpeter JA. The theory of economic development. Harvard University Press, Cambridge; $2017 . \quad$ pp. 3-57. https://books.google.co.id/books?id=GB8xDwAAQBAJ\&printsec= frontcover\&dq=the+theory+of+economic+development\&hl=en\&sa=X\&ved= OahUKEwiDIZPk3NrIAhVOXSsKHTHDB4YQ6AEIKTAA\#v=onepage\&q=the\% 20theory\%20of\%20economic\%20development\&f=false

[3] Leonard-Barton D. Core capabilities and core rigidities: a paradox in managing new product development. Strategic Management Journal 1992;13(S1):111--125. https: //onlinelibrary.wiley.com/doi/abs/10.1002/smj.4250131009

[4] Sok P, O'Cass A. Achieving service quality through service innovation exploration-exploitation: the critical role of employee empowerment and slack resources. Journal of Service Marketing 2015; 29(2):137--149. https://www.emeraldinsight.com/doi/abs/ 10.1108/JSM-03-2014-0085

[5] Gustafsson A, Kristensson P, Schirr GR, Witell L. Service innovation. Business Expert Press, New York; 2016. pp. 150--169

[6] Lee YD, Chen SH, Kuo JH. Exploring the intellectual structure of organizational learning studies. European Journal of Research and Reflection in Management Sciences, 2014; 2(2):76--83. http://tweb.cjcu.edu.tw/journal_abstract/2015_01_15_04_48_52. 976.pdf.

[7] Bongard-Blanchy K, Bouchard C. Dimensions of user experience - from the product design perspective. Journal d'Interaction Personne-Système, Association Francophone d'Interaction Homme- Machine (AFIHM), 2014, 3 (1), https://www. 
researchgate.net/publication/278828656_Dimensions_of_User_Experience__from_the_Product_Design_Perspective

[8] Choi MW. A study on the application of user experience to ICT-based advertising. International Journal of Pure and Applied Mathematics, 2018; 120 (6). https:// acadpubl.eu/hub/2018-120-6/issue4.html

[9] Pikas, E., Oehmen, J., Koskela, L., \& Thuesen, C. A new framework for construction project definition stage. 2018. In DS92: Proceedings of the DESIGN 2018 15th International Design Conference. DESIGN METHODS. Marjanović D, Štorga M, Škec S, Bojčetić N, Pavković N (Eds.). pp. 1301--1312. https://orbit.dtu.dk/files/149481728/ Contribution542_final_A.pdf

[10] Norman DA. The design of everyday things. Revised and expanded edition. Basic Books, New York; 2013. Pp. 1--347. https://www.goodreads.com/book/show/ 17290807-the-design-of-everyday-things

[11] Golightly D, Sharples S, Patel H, Ratchev S. Manufacturing in the cloud: A human factors perspective. International Journal of Industrial Ergonomics 2016; 55:12--21. https://www.sciencedirect.com/science/article/pii/S0169814116300464

[12] Tomico O, Mizutani N, Levy P, Takahiro Y, Cho Y. Kansei physiological measurements and constructivist psychological explorations for approaching user subjective experience during and after product usage. In: The $10^{\text {th }}$ International Design Conference. DS 48: Proceedings DESIGN 2008. Marjanovic D, Storga M, Pavkovic $\mathrm{N}$, Bojcetic $\mathrm{N}$ (Eds.). pp. 529--536. https://www.researchgate.net/publication /230561428_Kansei_physiological_measurements_and_constructivist_psycholog ical_explorations_for_approaching_user_subjective_experience

[13] Norman DA. Emotional design: Why we love (or hate) everyday things. Basic Books, USA; 2004. p. 161. https://www.amazon.com/Emotional-Design-Love-EverydayThings/dp/0465051367

[14] Salvia G, Rognoli V, Malvoni E, Levi M. The objectivity of users' emotional experience with textiles biological and mechanical tests for the prediction of the sensorial profile of fabrics. In: Seventh International Conference on Design and Emotion 2010. pp. 1--12. https://zenodo.org/record/2596735

[15] Hassenzahl M. User experience: A research agenda. In: Encyclopedia of HumanComputer Interaction. Soegaard M, Dam RF (Eds.). The Interaction Design Foundation, Denmark; 2011. pp 1--14. https://www.researchgate.net/publication/ 259823352_User_Experience_and_Experience_Design 